\title{
Isolation and quarantine in South Africa during COVID-19: Draconian measures or proportional response?
}

\author{
K Moodley, ${ }^{1}$ MB ChB, MFamMed, FCFP (SA), MPhil (Applied Ethics), Executive MBA, DPhil; \\ A E Obasa, ${ }^{1}$ BSc (Med Sci), MSc, PhD (Medical Virology); L London, ${ }^{2}$ MB ChB, MMed, MD, BSc (Med) Hons, DOH, FCPHM (SA) \\ ${ }^{1}$ Centre for Medical Ethics and Law, Department of Medicine, Faculty of Medicine and Health Sciences, Stellenbosch University, Cape Town, South Africa \\ ${ }^{2}$ School of Public Health and Family Medicine, Faculty of Health Sciences, University of Cape Town, South Africa
}

Corresponding author: K Moodley (km@sun.ac.za)

\begin{abstract}
In the midst of an unprecedented public health crisis, extraordinary containment measures must be implemented. These include both isolation and quarantine, either on a voluntary basis or enforced. In the transition from voluntary to mandatory isolation, conflicts arise at the intersection of ethics, human rights and the law. The Siracusa Principles adopted by the United Nations Economic and Social Council in 1985 and enshrined in international human rights legislation and guidelines specify conditions under which civil liberties may be infringed. In order for isolation processes in South Africa to claim legitimacy, it is important that these principles as well as national laws and constitutional rights are embedded in state action.
\end{abstract}

S Afr Med J 2020;110(6):456-457. https://doi.org/10.7196/SAMJ.2020.v110i6.14842

South Africa (SA) is currently in the midst of an unprecedented public health crisis. The transmission dynamics of COVID-19 mean that person-to-person spread is a serious public health risk. As such, the SA National Department of Health has invoked the Disaster Management Act, ${ }^{[1]}$ and several extraordinary containment measures have been implemented as part of a national lockdown to limit the spread of infection. A recent report in the Daily Maverick refers to a move from 'self-isolation' to enforced isolation in 'government approved isolation sites for treatment' in a phase described as 'concomitant punishment' in Durban, KwaZulu-Natal (KZN). The change in strategy appears to have been triggered by the high proportion of cases in eThekweni District (383/587) and the high mortality in KZN, with the province accounting for 22 of the 54 deaths in SA as of 20 April 2020. ${ }^{[2]}$

\section{Isolation $v_{0}$ quarantine}

During disease outbreaks, isolation and quarantine are wellestablished containment strategies. Although the terms are sometimes used interchangeably, isolation usually applies to those who are infected, contagious and a threat to public health. The concept of quarantine applies to someone who may have been exposed to or was in contact with an infected person and is the oldest containment strategy, dating back to the 14 th century ${ }^{[3]}$ In both cases, separation of persons from society may be voluntary or enforced. The success of these measures depends on the incubation period of the virus in influenza, isolation is usually not effective owing to a very short incubation period, while in COVID-19, with a longer incubation period (time before viral shedding), it is regarded as an effective containment strategy. Another factor contributing to success is prompt and efficient testing and contact tracing. ${ }^{[4]}$ Although the concepts of isolation and quarantine are familiar in SA in the context of tuberculosis (TB), which is a notifiable disease, any form of quarantine imposes a limitation on rights and is therefore fraught with ethical and human rights concerns.

\section{Infringement on civill liberties}

The public health justification for isolation or quarantine is undisputed. However, civil liberties will of necessity be infringed, and historically, such limitations on individual liberties have been associated with abuse and discrimination. ${ }^{[5]}$ The World Health Organization (WHO) has advised (in respect of isolation of TB patients) that any restrictions must be applied as a 'last resort' and justified only after 'all voluntary measures to isolate a patient have failed. ${ }^{\text {'6] }}$ Safeguards are therefore necessary, in terms of the law but also in terms of human rights frameworks. The Siracusa Principles on the Limitation and Derogation Provisions in the International Covenant on Civil and Political Rights ${ }^{[7]}$ were adopted by the United Nations Economic and Social Council in 1985 and are now firmly enshrined in international human rights law and standards. These principles are reflected in section 36 of the Constitution of South Africa, ${ }^{[8]}$ dealing with limitation of rights. According to these principles, any restriction on human rights must be based in law. The National Health Act No. 61 of $2003,{ }^{[9]}$ via regulations relating to the surveillance and the control of notifiable medical conditions, makes provision for testing, quarantine and isolation for notifiable diseases. Furthermore, restrictions imposed via isolation or quarantine must be based on a legitimate objective and must be strictly necessary for the achievement of the policy objective. In the case of COVID-19, the objective of preventing spread of infection in the public interest is clear. In KZN, the spread is particularly concerning. However, in operationalising the isolation or quarantine procedure, the least restrictive and intrusive means must be used and the burden of justifying a limitation of human rights lies with the state.

\section{Isolation as 'concomitant punishment'?}

It is unclear how the isolation process is actually being implemented, given that it is described in the media as 'concomitant punishment'. Notably, the COVID-19 regulations describe the obligation on the 
state to establish sites for quarantine and self-isolation for people who cannot isolate or quarantine in their homes. ${ }^{[1]}$ This implies some evaluative decision as to who should be subjected to such measures, but no guidance is given as to how such decisions are to be made consistent with human rights and dignity. The SA Bill of Rights $^{[8]}$ (section 36) insists that any limitation must be 'reasonable and justifiable in an open and democratic society based on human dignity, equality and freedom' and that the restriction (which will limit freedom of movement and potentially other rights, such as dignity or safety for a limited period) is proportional to the purpose of the limitation. Finally, such restrictions must be based on scientific evidence and should not be arbitrary, discriminatory or unreasonable. What is important is that all the conditions mentioned must be met to comply with the Siracusa principles and the Bill of Rights before the restrictions can be implemented. The WHO advises further that any limitation on rights must be for a limited period and subject to review and appeal. ${ }^{[6]}$ In addition, others have argued that people who have been isolated in this manner should be compensated in some way, based on the principle of reciprocity. ${ }^{[10]}$ Such compensation is related to the inconvenience of being removed from society to protect others. Legally, section 2(2) of the regulations in the National Health $\mathrm{Act}^{[9]}$ requires the government to take account of 'full respect for the dignity, confidentiality, human rights and fundamental freedoms of persons' when implementing measures that restrict civil liberties.

\section{Democratic legitimacy}

While limitation of rights may occur in the public interest in the context of a pandemic, it is also important that it does not have the paradoxical effect of increasing spread of infection and public risk. This would be the case if there is fear, intimidation, abuse or victimisation. Under such circumstances the aim of containing the infection will be defeated, as patients avoid testing for fear of what they see as incarceration. ${ }^{[1]}$ This, in turn, may defeat the purpose of the policy and render any rights limitations under the policy unjustifiable. While quarantine measures are an accepted containment strategy in public health emergencies, and they may be both legally and ethically justifiable under particular circumstances, a fair measure of compassion, restraint and respect for human rights must accompany them. Such an approach serves to ensure democratic legitimacy ${ }^{[12]}$ with measures our Bill of Rights envisages as compatible with human dignity, equality and freedom in an open and democratic society.

\section{Declaration. None}

Acknowledgements. None.

Author contributions. KM wrote the first draft and conducted the initial literature search. AEO assisted with the literature search, read and approved all versions and checked references. LL contributed to the article, added references and read and approved all drafts.

Funding. None.

Conflicts of interest. None.

1. Republic of South Africa. Disaster Management Act 57 of 2002 as amended. https://www.gov.za/ documents/disaster-management-act-declaration-national-state-disaster-covid-19-coronavirus-16mar (accessed 22 April 2020).

2. Erasmus D. KZN enters its 'concomitant punishment' phase on Monday as lockdown is intensified. Daily Maverick, 20 April 2020. https://www.dailymaverick.co.za/article/2020-04-20-kzn-enters-itsconcomitant-punishment-phase-on-monday-as-lockdown-is-intensified/ (accessed 21 April 2020).

3. Cetron MS, Simone P. Battling 21st-century scourges with a 14th-century toolbox. Emerg Infect Dis 2004;10(11):2053-2054. https://doi.org/10.3201/eid1011.040797_12

4. Wilder-Smith A, Freedman DA. Isolation, quarantine, social distancing and community containment: 4. Wilder-Smith A, Freedman DA. Isolation, quarantine, social distancing and community containment:
Pivotal role for old-style public health measures in the novel coronavirus (2019-nCoV) outbreak. J Pivotal role for old-style public health measures in the novel coronaris

5. Parmet WE. Legal power and legal rights - isolation and quarantine in the case of drug-resistant tuberculosis. N Engl J Med 2007;357:433-435. https://doi.org/10.1056/NEJMp078133

6. World Health Organization. WHO guidance on human rights and involuntary detention for XDR-TB control. https://www.who.int/tb/features_archive/involuntary_treatment/en/ (accessed 22 April 2020).

7. United Nations Economic and Social Council. Siracusa Principles on the Limitation and Derogation Provisions in the International Covenant on Civil and Political Rights. https://www.refworld.org/ pdfid/4672bc122.pdf (accessed 21 April 2020).

8. South African Government. Constitution of the Republic of South Africa, 1996. https://www.gov.za/ documents/constitution-republic-south-africa-1996 (accessed 22 April 2020).

South African Government National Health Act 61 of 2003. https://www govza/documents/nationalhealth-act (accessed 22 April 2020).

10. DaSilva DS, Smith MJ. Commentary: Limiting rights and freedoms in the context of Ebola and other public health emergencies: How the principle of reciprocity can enrich the application of the other public health emergencies: How the principle of reciprocity can enrich the application of the
Siracusa Principles. 2015. Health Human Rights I 2015;17(1). https://www.hhriournal.org/2015/06/ commentary-limiting-rights-and-freedoms-in-the-context-of-ebola-and-other-public-healthcommentary-limiting-rights-and-freedoms-in-the-context-of-ebola-and-other-public-health-
emergencies-how-the-principle-of-reciprocity-can-enrich-the-application-of-the-siracusa-principles/ (accessed 21 April 2020)

11. Parmet WE, Sinha MS. COVID-19 - the law and limits of quarantine. N Engl J Med 2020;382:e28. https://doi.org/10.1056/NEJMp2004211

12. Zarifi S, Powers K. Human rights in the time of COVID-19: Front and centre. International Commission of Jurists, 6 April 2020. https://www.icj.org/human-rights-in-the-time-of-covid-19front-and-centre/ (accessed 21 April 2020).

Accepted 22 April 2020 